\title{
First prosecution under Assisted Human Reproduction Act ends in conviction
}

A Canadian fertility agency owner was convicted on three counts under the Assisted Human Reproduction Act, the firstever prosecution under the nine-yearold law.

Leia Picard, who runs Canadian Fertility Consultants (CFC), based in Brighton, Ontario, pleaded guilty to purchasing eggs, paying surrogates and taking money to arrange surrogacies. Her company also pleaded guilty to the first two charges. Picard and CFC were fined a combined $\$ 60000$.

"This is a warning to clinics who have been dabbling in this," says Dr. Arthur Leader, cofounder of the Ottawa Fertility Centre in Ottawa, Ontario.

CFC works with people who want to have children with the help of egg donors or surrogates. The law does not ban egg donation or surrogacy, but it prohibits payment for these services and for arranging surrogacies.

Complaints received in 2011 that Picard was contravening the reproduction act led to an RCMP investigation. Charges were laid in February 2013. According to court documents, CFC paid a flat fee of $\$ 5000$ to egg donors and created "fictitious" or "estimated" expenses to make it appear that donors were being reimbursed for legitimate expenses rather than being paid a fee. But the amounts far exceeded actual expenses, RCMP interviews determined.

Similarly, Picard paid a flat fee of about $\$ 1950$ per month to surrogates, plus additional payments for embryo transfers, positive pregnancy tests, carrying twins and undergoing cesarean deliveries. The RCMP found that payments were made regardless of actual expenses incurred. CFC did ask for receipts from surrogates but many were for expenses unrelated to surrogacy, such as rent, entertainment-related purchases, car insurance, Internet and utility bills. Often, the envelopes containing the receipts were never even opened.

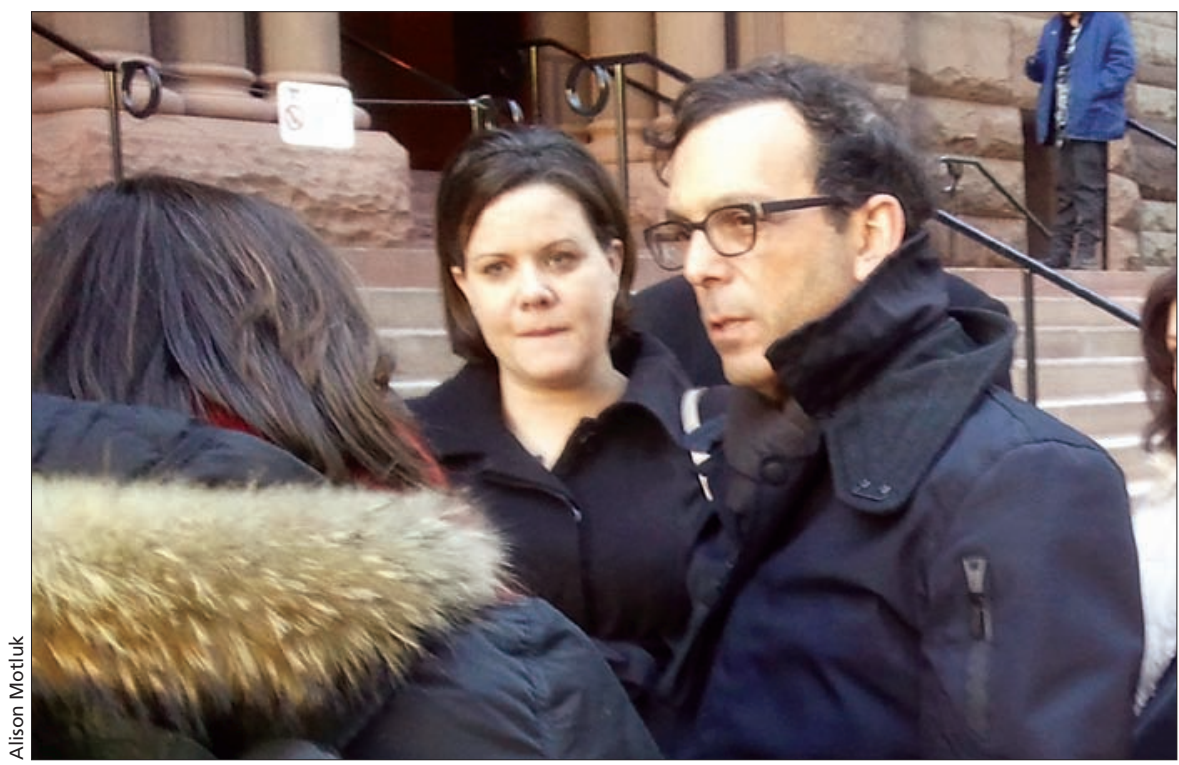

Leia Picard looks on as her lawyer, Frank Addario, answers questions from the press after the guilty plea.

The third count against Picard stemmed from payments she received from US fertility lawyer Hilary Neiman, who sent surrogates to foreign countries for in vitro fertilization and then looked for prospective parents. Neiman would tell prospective parents that the original couple had backed out and falsified pre-birth orders to get around the US adoption process. (Neiman and her associates were convicted in 2011 and served time in jail.)

Canadian recipient couples paid as much as $\$ 149000$ to assume the surrogacies. On three occasions, Picard, who says she was unaware of the deception, found parents for Neiman and was paid $\$ 31000$ in "referral fees." Because Picard accepted money but provided no consulting services to parents, she was deemed to have violated the Canadian law.

Diane Allen, who heads the patient support group Infertility Network, believes the connection to Neiman might explain why the government finally acted, after years of ignoring evidence of wrongdoing. "Would it have been embarrassing if they didn't do anything?"

The crown prosecutor acknowledged that Picard had shown remorse by pleading guilty and that she had no criminal record. But he told the court that the violations had been "long, systemic and deliberate" and that Picard had "made efforts to conceal her actions."

"There's no question that she crossed the line," said defence lawyer Frank Addario outside the courtroom. "But there will still be people who will be confused about the limits of the law and how to govern themselves."

$\mathrm{He}$ was referring to the fact that Health Canada has never released regulations stipulating what expenses can be legitimately reimbursed, which has created widely differing interpretations of what is legal. "Law-abiding Canadians should be able to know what the law is so they can act in accordance," says Françoise Baylis, Canada Research Chair in Bioethics and Philosophy at Dalhousie University in Halifax, Nova Scotia. Baylis has 
been pressing Health Canada for clarity without success.

Leader says that Health Canada has failed in its duty to define what is allowed. He points out that it's been 20 years since the Royal Commission on New Reproductive Technologies published its findings, almost 10 years since the reproductive act came into force and three years since the Supreme Court affirmed this was an important federal issue. "But the only way you discover whether you're doing anything wrong," he says, "is when someone complains or the RCMP is on your doorstep."

The fact that Picard and CFC were never charged for accepting money for their regular consulting services, which often involved helping intended parents find surrogates, raises the question of what the law's prohibition on "arranging" surrogacy actually means, says Sara Cohen, a fertility lawyer in Toronto, Ontario.

"It's curious that in the cases where she was charged with paying a surrogate she wasn't also charged for arranging the services," Cohen notes.

For Dr. Mathias Gysler, medical director of the ISIS Regional Fertility Centre in Oakville, Ontario, the conviction provides no clarity. "I'm waiting for Health Canada and the government to tell me what's okay."
Health Canada, however, claims it provides clear explanations and examples of allowable reimbursements for donors and surrogates on its website. "It is clear under the act that payments to egg donors and surrogates are illegal in Canada," states an email from Leslie Meerburg, a media relations advisor for Health Canada. "However, it is legal to reimburse donors and surrogates for expenditures directly related to their donations or their pregnancies, such as travel to medical appointments and medications." - Alison Motluk, Toronto, Ont.

CMAJ 2014. DOI:10.1503/cmaj.109-4687 